\title{
Design Strategies Study on Self-timer Camera Based on User Study ${ }^{1, a}$ Feng Yi \\ ${ }^{1}$ College of Arts and Design, Beijing Forestry University, Beijing, China, 100083 afengyid@163.com
}

Keywords: Product image; style design; brand analysis; user study.

\begin{abstract}
With the quick development in social network and social demand needs of people, self-timer has become the photography manner popular with consumers. The aim of investigation is to provide basis for the design direction of self-timer camera through study on consumption digital camera with self-timer function. The investigation steps include analysis on similar products, brand study, user interview and construction of user role.
\end{abstract}

\section{Introduction}

With the rapid development in social network and changes of people’s social demand, self-timer has become the manner popular with the young consumers. This paper makes study on position of design strategy of self-timer digital camera of the next generation through consumption digital camera with self-timer function; it provides design direction to develop the products suitable for consumer demand, so that it can enhance the market competition of self-timer digital camera.

\section{Plan design studied by user}

Aim and content of user investigation:It makes clear the design state of self-timer digital camera through market investigation on consumption digital camera with self-timer function, it makes investigation and analysis on consumption behavior, consumption preference, usage manner and life style of targeted consumers, so that it makes study on potential demand of targeted consumers and provides design direction and position for development of self-timer digital camera.

The investigation content of self-timer digital camera is as follows:

a. Analysis on similar competition product. It makes classification and comparison for appearance, price, consumption group, and distribution state etc of different products, so it uses this to compare advantages and disadvantages of each competition product.

b. Brand study on fashionable self-timer digital camera. It analyzes its advantage and disadvantage, gets design features and design principle of product through study on development history of representative self-timer digital camera such as CASIO etc.

c. User research and behavior analysis. It summarizes consumption trend and explores the potential consumers by learning effect of current product on users by cause analysis in aspects of user psychology, behavior, usage habit etc.

Method on user investigation :This investigation adopts investigation method of background literature, field investigation, interview, shadow tracing, questionnaire and observation; it makes investigations on users of different sex and age. The investigation object mainly uses consumers in Beijing and the other are consumers away from Beijing. The preliminary aim of user investigation is to help enterprise to define targeted use group of product, make clear and refine design concept and position of product, making users' actual demand turn into design orientation of product through study on user behavior, perception and cognitive psychological characteristics, so that it can make the developing product suitable for user's habit, experience and expectation.

\section{User investigation}

This paper adopts questionnaire and interview method and summarizes the causes in aspects of user' psychology, behavior, usage habit etc by learning effect of current product on target user, it also 
summarizes consummation trend and explores potential consumers. The investigation divided target users into three age levels and gets multiple-level investigation by way of distributing questionnaire in level, which guarantees the comprehensiveness of questionnaire.

Questionnaire:The design team selects 30 target consumers to carry out questionnaire; it is composed by the following parts:

a) The daily life and behavior of users, what they usually do and do what in their spare time.

b) The social manner of users and how they carry out social on the internet.

c) Photography manner, when and where, how they deal with the photos and whether it is self-timer or not.

Behavior analysis on users of each age level :The investigation finds that target users can be divided into three age levels, their behavior characteristics of each age level is indicated in the following table.

Table 1 Behavior characteristics of target users

\begin{tabular}{|c|c|c|}
\hline Age stage & Career & Behavior characteristics \\
\hline $15-25$ & $\begin{array}{lr}\text { Middle } & \text { school } \\
\text { students, university } \\
\text { students and young } \\
\text { people just starting } \\
\text { working }\end{array}$ & $\begin{array}{l}\text { many kinds of amusement } \\
\text { manners, they are food of } \\
\text { network social such as } \\
\text { Renren, micro-blog, } \\
\text { micro-massage etc }\end{array}$ \\
\hline $25-35$ & $\begin{array}{lr}\text { The officer } & \text { workers } \\
\text { already } & \text { started } \\
\text { working } & \end{array}$ & $\begin{array}{l}\text { The self-timer photos are } \\
\text { most family or amusement } \\
\text { photos. They emphasize on } \\
\text { quality and have stronger } \\
\text { ability to accept new things }\end{array}$ \\
\hline
\end{tabular}

A)The consumers of ages from 15 to 25: they are middle school students, university students and the young people just start working, there are many kinds of amusement manners, they are food of network social such as Renren, micro-blog, micro-massage etc, they are fond of watching friends photos and carrying photography equipment when travelling, they usually record the things in life and upload to the social website.

B)The consumers of ages from 25 to 35: they are the young people or some scholars already started working, some are married. They inherit the habit from student times on usage of social website. Self-timer photos are most family or amusement photos. They emphasize on quality in consumption manner and have stronger ability to accept new things.

C) The consumers of ages from 35 to 45: they are already married and their careers are in the stable period. They are not so keen on social website; they seldom use mobile social App. They have little photography behavior and they never have self-timer behavior. They emphasize on quality and practicability in consumption.

According to market investigation, the writer finds that the young consumer groups of ages from 15 to 25 are the future users of self-timer digital camera. They seek fashion and trend and like products with small volume, low price and modern appearance and personalization.

\section{Data analysis on user study}

Market introduction of selfotimer camera :With the mature of digital camera in production technology, the price of card digital camera is not so expensive in the early period, now the consumers only need to spend several hundred Yuan to buy one card digital camera. Therefore, the market of card digital camera is faced with serious test, this kind of product goes toward the crossroads in market survival, on one hand, it is faced with challenges from single camera and SLR camera, on the other hand, it subjected to strong restriction by intelligent camera. While self-timer camera seek new path in meeting self-timer demand of customer and brings new usage experience by innovated product structure and usage manner. The typical representative self-timer camera has 
CASIO TR series digital camera, it is regarded as self-timer artifact since come into market by the young females. This kind of camera has designed rotating outline boarder of 360 degree, it has gesture self-timer and beautification function, which can make the people in photo much more beautiful and meet demand of special users.

Self-timer digital camera is also faced with market challenges from intelligent mobile phone camera, single camera and SLR camera, due to technology development, the photo effect of intelligent mobile phone is becoming increasingly stronger, it has become the best self-timer choice for people, in addition, the single camera and micro SLR camera with rotating boarder and some professional consumption camera have better self-timer function, the consumers emphasize on self-timer have more choices.

Analysis on similar competitive product:According to the data of investigation center of network consumption center in 2011, it gets the following conclusion: in the consumption digital camera market of China, Canon, Nikon, Sony firmly occupy the three largest leading position, next is Fuji and Samsung, of which the attention of Canon nearly approaches 30\%, Sony $20.6 \%$, Nikon $11 \%$. The attention of Panasonic, Olympus, Casio, Pentax, and Kodak listed in rank from sixth to 10th, the attention percent is almost below 5\%. Although its brand has higher popularity in consumers, it has no obvious superiority in certain field, so its performance in the overall market is not so good as the above mentioned 5 brands.

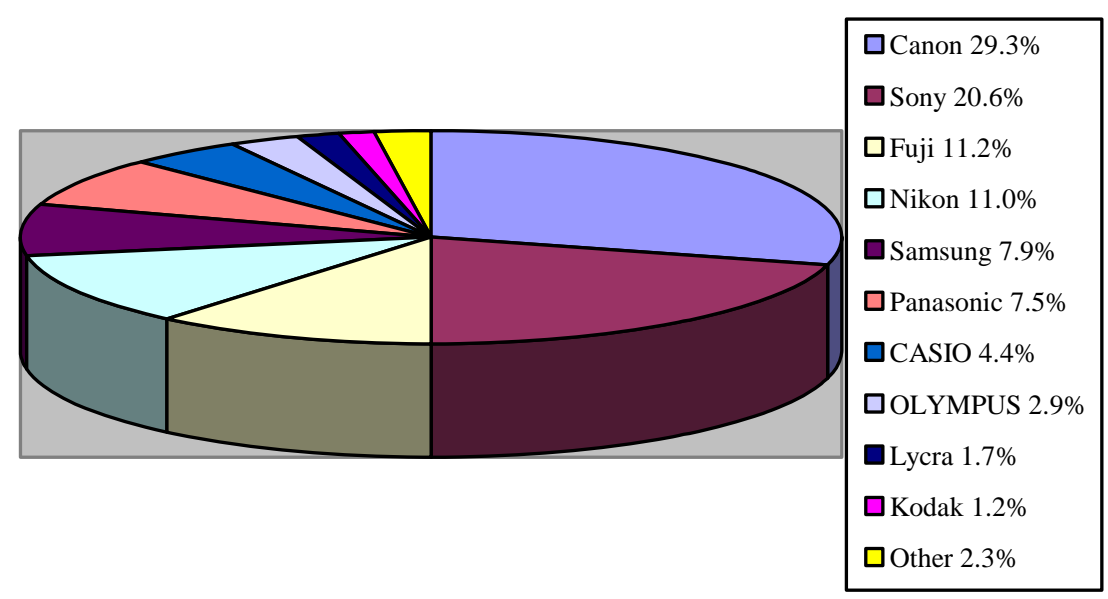

Figure 1 Market and brand distribution of digital camera

The consumption camera is popular with users, its main audiences are the white-collar with consumption ability, it also has stronger attraction for the student market becoming stronger day by day. It mainly has the following cause: most audiences of card digital camera have no much professional photography knowledge, camera is used mainly in travelling or life photography, in their life, shooting may not one mainstream activity, but it turns to be one thing has to prepare, they like product with easy operation and good quality, and they do not want to spend time in choice and repair, they have certain quality pursuit, they believe I brand and have certain fund basis.

It divides domestic consumption camera market into 6 levels by product price, its price is less than 1000Yuan, 1000 to 2000 Yuan, and 2000 to 4000 Yuan and above 4000Yuan, we can see that the product between 1000 and 2000 attracts the most attention, achieves $56.3 \%$. In contrast, the price below 1000 Yuan and above 4000 Yuan has little percent in attention. According to monitoring of consumption camera in China in the half year by ADC, the average price of consumption camera market has decreased to below 1500Yuan. ADC predicts that the attention from 2000 to 4000 Yuan will gradually have the situation of turning to range of 1000 to 2000. 


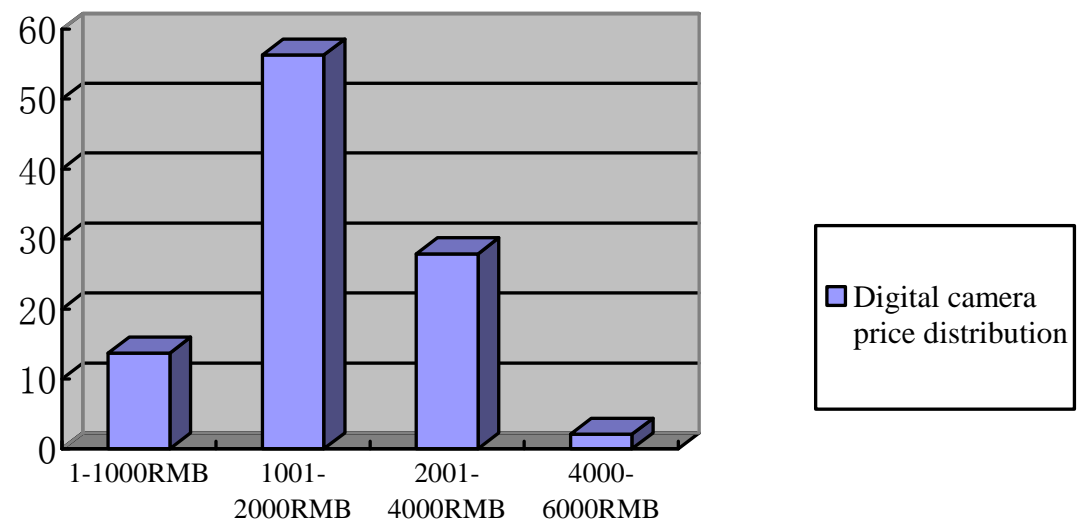

Figure.2 Market and brand distribution of consumption digital camera

Analysis on design of typical brand:By comparing with pattern of each series of camera production in CASIO digital camera, it analyzes the product DNA of CASIO digital camera, finds its curve change of each camera model is mainly focus on the central symmetric line. The design characteristic of self-timer digital camera is divided into the following conditions: a) it distributes series nameplate decoration along the lateral line, b) it has ridge design in the midline of product, which enriches appearance details of products, c) it has convex curve design in the left of lens, which has decoration effect.

CASIO digital camera has very high occupation in Japanese market; CASIO and Canon respectively occupy the first and the second share. While in Chinese market, CASIO is left behind, which indicates that Chinese market and Japanese market is different, Chinese consumers pay more attention to appearance design of product, advertisement propaganda of brand. From the Q1 financial report and market statistics data in this year an last year, the route of card camera with special function has taken effect, it has precisely positioned target population to develop products with targeted, novel functional.

\section{Design strategy}

The general idea and overall direction of self-timer digital camera is concise, beautiful, affinity, fashionable and modern, and at the same time it is easy to operate, its design emphasizes on usability and individuation in appearance. The shape and color are the direct factors for self-timer digital camera to communicate emotional with users, they will directly affect the sensory experience of consumers, it is the first perceptual factor. According to research on target consumption group by design team, self-timer digital camera should connect with the fashionable trend of digital product in current times, it also should make consumers experience their usage pleasure, they can timey share photos and pleasure with friends by joining in WIFI function etc

\section{Conclusion}

Self-timer digital camera is most popular with young consumers. Through research on user behavior, psychology and usage habit, the design team explores the causes from deeper level so as to seek chance of new product design. It should integrate the users' behavior and psychology research into the while process of design, as the big manufacturing country. Self-timer digital camera enterprises in China should actively face with user' demand and adapt to market competition. It should grasp the core demand and consumption preference of users, learn users like what kind of products, and make research on the real aim of user buying and using product, which is helpful to make design strategy with market competition. 


\section{References}

[1] CHOI Seung-jin,BURGESS Gar y.Practical Mathematical Model to Predict the Performance of Insulating Packages[J].Package Techno Sic,2007,20:369-380.

[2] SINGH S P,BURGESS G,SINGH J.Performance Comparison of Thermal Insulated Packaging Boxes,Bags and Refrigerants for Sing Le-parcel Shipments[J].Package Techno Sic,2008,21:25-35.

[3]Xu Yuanguo. Industrial Design, Value Enhancement of ODM and Exported Product of China: Effect Mechanism and Demonstration Test [J]. Problem of International Trade, 2013, 01:146-157.

[4]GAN Yan. Analysis of the method on industrial design guided by individual spontaneous behavior[J]. Computer Aided Drafting,Design and Manufacturing,2012,04:59-62.

[5]DAI Zheng,ólafur ómarsson. The combination of user centered design and industrial design: Balance between subjective and objective design[J]. Computer Aided Drafting,Design and Manufacturing,2012,04:63-68.

[6]Xiong Hong, Wang Xiaoping, Le Wande, Huang Ting. Design and Realization in Comprehensive Evaluation System of Mechanical and Electrical Products [J]. Journal of Central South University (Nature and Science version), 2005, 04:637-641.

[7]Liu Xiaojun, Zhang Mier, Li Kun. Research on Effect Trend of Industrial Design in Industry and Technology Evolution [J]. Science and Management of Science Technology, 2009, 03:165-169.

[8]Wu Zhijun, Li Liangzhi, Chen Yu, Cai Yan. Topic on Industrial Design and its Research [J]. Originality and Design, 2010, 06:47-52.

[9]. The Scope of Design Studying[J]. Science and Technology Information (Research), 2007,11:123-124.

[10]Luo Shijian, Zhu Shangshang, Feng Pin. Product Design DNA Faced with Industrial Design [J]. Mechanical Engineering Journal, 2008, 07:123-128. 